\title{
Macronutrients and Micronutrients Variability in Soybean Seeds
}

\author{
Rodrigo L. de Vargas ${ }^{1}$, Luis O. B. Schuch ${ }^{1}$, Willian S. Barros ${ }^{1}$, Geliandro A. Rigo ${ }^{1}$, Vinícius J. Szareski ${ }^{1}$, \\ Ivan R. Carvalho ${ }^{1}$, João R. Pimentel ${ }^{1}$, Cristian Troyjack ${ }^{1}$, Lanes B. A. Jaques ${ }^{1}$, Velci Q. de Souza ${ }^{2}$, \\ Tiago C. da Rosa ${ }^{1}$, Tiago Z. Aumonde ${ }^{1} \&$ Tiago Pedó \\ ${ }^{1}$ Federal University of Pelotas, Capão do Leão, RS, Brazil \\ ${ }^{2}$ Universidade Federal do Pampa, Dom Pedrito, RS, Brazil \\ Correspondence: Vinícius J. Szareski, Federal University of Pelotas, Capão do Leão, RS, Brazil. E-mail: \\ viniciusszareski@gmail.com \\ Ivan R. Carvalho, Federal University of Pelotas, Capão do Leão, RS, Brazil. E-mail: carvalho.irc@gmail.com
}

Received: October 30, 2017

Accepted: January 4, 2018 Online Published: March 15, 2018

doi:10.5539/jas.v10n4p209

URL: https://doi.org/10.5539/jas.v10n4p209

\begin{abstract}
The objective of this work was to evaluate the chemical composition of the macronutrients: nitrogen $(\mathrm{N})$, phosphorus $(\mathrm{P})$, potassium $(\mathrm{K})$, calcium $(\mathrm{Ca})$, magnesium $(\mathrm{Mg})$ and sulfur $(\mathrm{S})$, and micronutrients: boron $(\mathrm{Cu})$, iron $(\mathrm{Fe})$, manganese $(\mathrm{Mn})$, molybdenum $(\mathrm{Mo})$ and zinc $(\mathrm{Zn})$, and the elements aluminum $(\mathrm{Al})$ and sodium $(\mathrm{Na})$ measured in soybean seeds from different producing regions of Brazil. This work was carried out by sampling 2543 lots of soybean seeds produced in the 2009, 2010, 2011 and 2012 growing seasons. There is high variability of macro and micronutrients concentration in soybean seeds produced in several regions of Brazil. The nitrogen, potassium, phosphorus, and calcium are the most pronounced macronutrients in soybean seeds. Among the micronutrients, iron, manganese and zinc are those with more evidence. Understanding macro and micronutrients variability is critical for improving management and fertility treats in soybean seed production fields.
\end{abstract}

Keywords: nutritional composition, minerals, interrelations

\section{Introduction}

Soybean cultivation is widely distributed in Brazil, as the country is the second largest producer of this crop in the world. The study about quality of soybean seeds has increased in the last years, considering its importance for establishing the field (Carvalho et al., 2015). Soybeans production in the 2016/2017 harvest was over 114 million tons in an area of 33 million hectares (CONAB, 2017).

The increase in soybean production in Brazil is due to technologies and inputs employed, which allow the cultivar to express its genetic and physiological potential (Demari et al., 2016). The advances achieved through genetic breeding are transferred to farmers by the seeds, therefore, high yielding fields begin with an adequate stand of plants, which depends on the utilization of high quality seeds (Szareski et al., 2016). The term seed quality is defined as a set of characteristics that determine their value for sowing, and their performance potential can only be consistently identified when considering the interactions among genetic, physical, physiological and sanitary attributes (Peske et al., 2012).

Among the factors affecting seed quality, it may be mentioned the availability of nutrients in the soil, since seeds with adequate nutrient content have high capacity to generate vigorous and productive plants (Pelegrin et al., 2016). Thus, seeds should be produced in areas with high nutrient availability to the plants, achieving not only higher yields but also seeds of better quality (Marcos Filho, 2015).

The reserve substances contained in seeds are responsible for supplying the energy and minerals necessary to fully manifest their vital functions, as well as affecting their storage potential (Meier et al., 2016). The macro and micronutrients contained in the seeds are necessary for seedlings development and establishment in the field (Magalhaes et al., 2015). Thus, seeds with high content of certain macro or micro nutrient may originate vigorous plants even in soils with deficiency of this nutrient. However, seed reserves are only enough to guarantee seedling emergence, and from this stage, the plant initial development in the field will mainly depend on soil fertility (Carvalho \& Nakagawa, 2012; Carvalho et al., 2016). 
Studies regarding seeds chemical composition are of practical interest for seed technology, since their physiological quality is characterized by influence seedlings initial development, biological nitrogen fixation in leguminous, and consequently the establishment of their initial stand in the field, as nutrient deficiency may lead to disorganization of initial metabolic processes up to grain yield (Coelho et al., 2002; Carvalho et al., 2017). The objectives of this work was to evaluate the chemical composition of the macronutrients: nitrogen $(\mathrm{N})$, phosphorus $(\mathrm{P})$, potassium $(\mathrm{K})$, calcium $(\mathrm{Ca})$, magnesium $(\mathrm{Mg})$ and sulfur $(\mathrm{S})$, and micronutrients: boron $(\mathrm{Cu})$, iron $(\mathrm{Fe})$, manganese $(\mathrm{Mn})$, molybdenum $(\mathrm{Mo})$ and zinc $(\mathrm{Zn})$, and the elements aluminum ( $\mathrm{Al})$ and sodium $(\mathrm{Na})$ measured in soybean seeds from different producing regions of Brazil.

\section{Material and Methods}

This work was carried out by sampling 2543 lots of soybean seeds produced in the 2009, 2010, 2011 and 2012 growing seasons. The seed lots were sampled through the Seed Analysis Laboratory of the company Dimicron Química do Brasil Ltda ${ }^{\circledR}$, in Cruz Alta - RS, Brazil. Posteriorly, they were sent to the Laboratory of Chemical Analysis of the Brazilian Institute of Analyzes located in Sumaré, SP. The study was based on a descriptive approach of 2543 seed lots, where 50 grams of seeds were sampled for each chemical determination of nutrients and elements (Malavolta, 1989). It was affeered the macronutrients: Nitrogen (N), Phosphorus (P), Potassium $(\mathrm{K})$, Magnesium (Mg), Calcium (Ca), Sulfur (S), the micronutrients: Boron (B), Copper (Fe), Manganese (Mn), Molybdenum (Mo), Zinc ( $\mathrm{Zn}$ ), and the elements Aluminum ( $\mathrm{Al}$ ) and Sodium (Na), being them.

Nitrogen $(N)$ : The semi-micro-Kjeldahl method was used based on the transformation of the ammoniacal nitrogen $\left(\mathrm{NH}_{4}\right)_{2} \mathrm{SO}_{4}$ into ammonia $\left(\mathrm{NH}_{3}\right)$, which is fixed by boric acid and then titrated with $\mathrm{H}_{2} \mathrm{SO}_{4}$ until a new formation of $\left(\mathrm{NH}_{4}\right)_{2} \mathrm{SO}_{4}$ in the presence of acid and base indicator, results in grams per pound of seeds $\left(\mathrm{g} \mathrm{kg}^{-1}\right)$.

Phosphorus $(P)$ : Determined by metavanadate colorimetry based on the formation of a yellow compound of the vanadomolibo phosphoric system in acidity from 0.2 to 1.6 N.A., with its color developed by photocolorimeter or spectrophotometer using a color filter complementary to the sample, measuring the percentage of transmission $(\% \mathrm{~T})$, absorbance (A) or optical density (O.D.), results in grams per kilogram of seeds $\left(\mathrm{g} \mathrm{kg}^{-1}\right)$.

Potassium (K): Obtained by atomic absorption spectrometry through the oxidation of the plant material by nitric-perchloric digestion, and then quantified by atomic absorption spectrophotometer with K-(Lc) hollow cathode lamp, results in grams per kilogram of seeds $\left(\mathrm{g} \mathrm{kg}^{-1}\right)$.

Calcium ( $\mathrm{Ca}$ ) and Magnesium ( $\mathrm{Mg}$ ): Measured by atomic absorption spectrophotometry for calcium and magnesium, using a calcium-magnesium or individual discharge arc lamp (or hollow cathode), being necessary the addition of lanthanum or strontium to prevent the interference caused by phosphates and aluminum, results in grams per kilogram of seeds $\left(\mathrm{g} \mathrm{kg}^{-1}\right)$.

Sulfur (S): Determined through sulfate turbidimetric based on the turbidity formed by sulfur precipitation by barium chloride, in the form of barium sulfate, turbidity measured in a colorimeter or spectrophotometer in the form of transmittance (T) or absorbance (A or D.O.), results in grams per kilogram of seeds $\left(\mathrm{g} \mathrm{kg}^{-1}\right)$.

Boron (B): Determined through $\mathrm{H}$ azomethine colorimetry, using the formation of a colored complex by the reaction of boric acid with the reagent $\mathrm{H}$ azomethine, results in grams per kilogram of seeds $\left(\mathrm{g} \mathrm{kg}^{-1}\right)$.

Copper $(\mathrm{Cu})$ : Obtained through atomic absorption spectrophotometry with scale expansion due to its low concentration in plants, results in grams per kilogram of seeds $\left(\mathrm{g} \mathrm{kg}^{-1}\right)$.

Iron ( $\mathrm{Fe}$ ): Measured by atomic absorption spectrophotometry, results in grams per kilogram of seeds $\left(\mathrm{g} \mathrm{kg}^{-1}\right)$.

Manganese $(\mathrm{Mn})$ : Determined by atomic absorption spectrophotometry using the appropriated hollow cathode lamp, results in grams per kilogram of seeds $\left(\mathrm{g} \mathrm{kg}^{-1}\right)$.

Zinc $(Z n)$ : Obtained through atomic absorption spectrophotometry using the appropriated hollow cathode lamp, results in grams per kilogram of seeds $\left(\mathrm{g} \mathrm{kg}^{-1}\right)$.

Sodium (Na): Measured by atomic absorption spectrophotometry using a respective hollow cathode lamp, results in grams per kilogram of seeds $\left(\mathrm{g} \mathrm{kg}^{-1}\right)$.

Aluminum ( $A l)$ : Determined by colorimetry of aluminum by dry matter oxidation through incineration process, measuring the color developed in spectrophotometer, results in grams per kilogram of seeds $\left(\mathrm{g} \mathrm{kg}^{-1}\right)$.

The data were submitted to a descriptive analysis for each measured trait, in order to determine the distribution frequency, amplitude and number of classes formed by each nutrient and elements measured in 2543 lots of soybean seeds. 


\section{Results and Discussion}

\subsection{Nitrogen ( $N$ )}

This mineral is highly required by plants, being available in the soil as ammonium, nitrate, aminoacids, peptides and complex insoluble forms. Plant species differ in their preference for nitrogen sources, where they mainly absorb inorganic forms such as nitrate $\left(\mathrm{NO}_{3}{ }^{-}\right)$or ammonium $\left(\mathrm{NH}_{4}{ }^{+}\right)$(Williams \& Miller, 2001). This element is closely linked to the production of important constituent proteins for embryo initial development during seeds germination, with great effects on grain yield. For grain filling, two sources of nitrogen are used, one originated from soil absorption and the other from remobilization of vegetative tissues (Ta \& Weiland, 1992).

In case of abiotic stresses due to drought or nitrogen deficiency, there is a possibility of remobilizing this element from vegetative tissues to the grains (Ta \& Weiland, 1992; Carvalho et al., 2013). Research by Carvalho and Nakagawa (2012) defines that nitrogen influence seeds physiological quality, however their effects depend on environmental conditions and plant development stage. Nitrogen levels (N) evidenced for the 2543 soybean seed lots presented a maximum value of $95 \mathrm{~g} \mathrm{~kg}^{-1}$ and a minimum of $22 \mathrm{~g} \mathrm{~kg}^{1}$, representing an amplitude of $73 \mathrm{~g} \mathrm{~kg}^{-1}$ (Figure 1). In a soybean seeds production system, it is estimated that about $57.82 \mathrm{~kg}$ of nitrogen are exported for producing one ton of seeds (Borket, 1986).

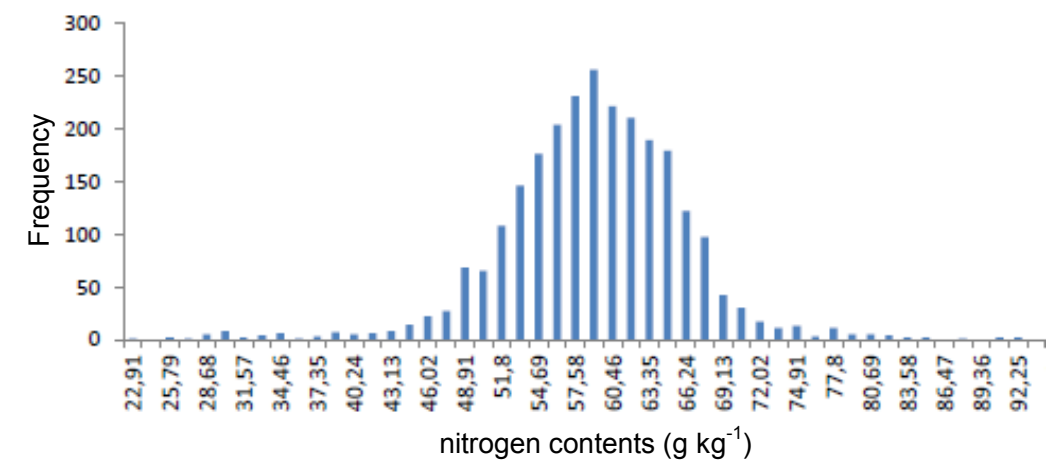

Figure 1. Frequency distribution histogram for nitrogen contents in 2543 soybean lots, expressed in $\mathrm{g} \mathrm{kg}^{-1}$

\subsection{Phosphorus $(P)$}

This nutrient is involved in energy transference (ATP) necessary for photosynthesis, translocation and metabolic processes (Shuman, 1994; Ferrari et al., 2014). It participates in the formation of reproductive structures, root development, fruit and seed formation (Raij, 1991; Follmann et al., 2014). The plant's reserve phosphate is in organic form as phytin in the seeds, and as inorganic form in vegetative tissues (Butler \& Jones, 1973). Research on several species shows that seedlings dry matter and plant production may increase with higher phosphorus levels in the seeds. It might occur in the absence or presence of phosphate fertilization (Bolland \& Baker, 1989). In situations of nutritional deficiency, the magnitudes of this nutrient tend to reduce biomass accumulation and soybean seed yield (Mengel \& Kirkby, 1987; Carvalho et al., 2015).

The increase of phosphorus concentration in the seeds improves phosphorus supplying for plants in early developing stages (Grant et al., 2001). According to Trigo et al. (1997), plants from seeds with higher phosphorus content improve their initial metabolic demand, as evidenced by tests such as first germination counting, seeding emergence at field, root length and aerial part. Among macronutrients, phosphorus is required in smaller quantities by soybean, and the amount of phosphorus applied to the soil, generally exceeds its extraction by the crop, in contrast, nitrogen $(\mathrm{N})$ and potassium $(\mathrm{K})$ differ in demand, and have a close relationship with productivity (Raij, 1991; Szareski et al., 2015).

The phosphorus content (P) in soybean seed lots had a maximum value of $10 \mathrm{~g} \mathrm{~kg}^{-1}$ and a minimum of $0,44 \mathrm{~g}$ $\mathrm{kg}^{-1}$, with a range of $9.56 \mathrm{~g} \mathrm{~kg}^{-1}$ in relation to maximum and minimum accumulations (Figure 2). In a soybean production system, for producing one ton of seeds, about $3.74 \mathrm{~kg} \mathrm{ha}^{-1}$ of phosphorus is exported in the harvest. Research with 1200 soybean lots from different regions of Brazil define an export of $10 \mathrm{~kg} \mathrm{ha}^{-1}$ of $\mathrm{P}_{2} \mathrm{O}_{5}$ (Borket, 1986), generally about $75 \%$ of the mineral phosphorus applied at sowing is exported to soybean seeds (Bataglia \& Mascarenhas, 1977; Pauletti, 2004; Ferrari et al., 2015). 


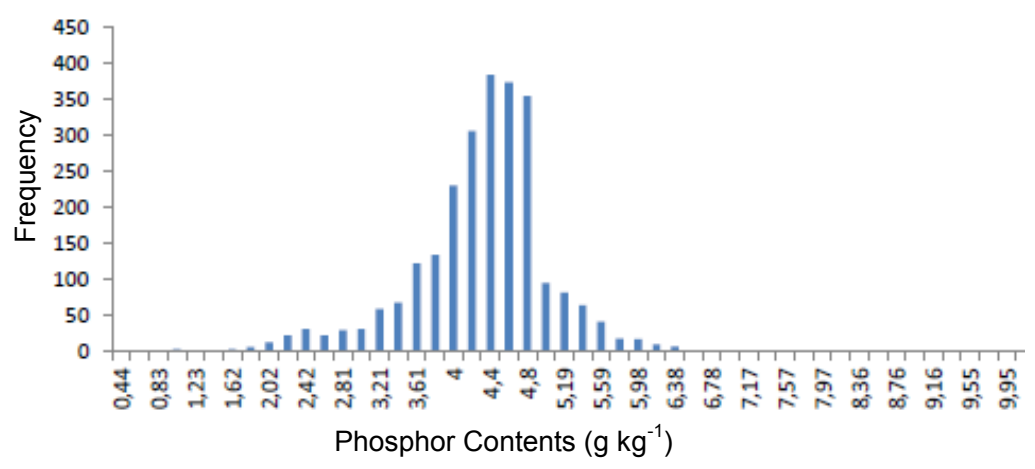

Figure 2. Frequency distribution histogram for phosphor contents in 2543 soybean lots, expressed in $\mathrm{g} \mathrm{kg}^{-1}$

\subsection{Potassium (K)}

This nutrient is predominantly found as free or adsorbed cation, and it may be easily translocated along cells or tissues in the plant (Lindhauer, 1985). This high mobility in the plants is due to functions and characteristics of this nutrient, which is the main cation used for neutralizing osmotic loads and actions (Clarkson \& Hanson, 1980; Souza et al., 2015). An adequate potassium nutrition promotes the increases in protein content, reserve carbohydrates, coloration, aroma, $\mathrm{C}$ vitamin content, soluble solids, and minimizes physiological disorders (Usherwood, 1985; Koo, 1985; Souza et al., 2015). The requirements of this nutrient for an adequate growth and development of plants are between 20 and $50 \mathrm{~g} \mathrm{~kg}^{-1}$ of dry tissues, however, soybean plants have the capacity of absorbing potassium amounts higher than their needs (Meurer, 2006).

Potassium (K) contents for the soybean seed lots presented maximum magnitudes of $52 \mathrm{~g} \mathrm{~kg}^{-1}$ and minimum of 1 $\mathrm{g} \mathrm{kg}^{-1}$, resulting in an amplitude of $51 \mathrm{~g} \mathrm{~kg}^{-1}$ between the extremes (Figure 3). In a soybean seeds production system, for each ton of seed produced, $18.42 \mathrm{~kg} \mathrm{ha}^{-1}$ of potassium is exported. Research with 1200 samples of plant tissue and soybean seeds from several growing environments in Brazil reveal that one ton of seeds exported about $20 \mathrm{~kg} \mathrm{ha}^{-1}$ of $\mathrm{K}_{2} \mathrm{O}$ (Bataglia \& Mascarenhas, 1977; Borket, 1986; Pauletti, 2004).

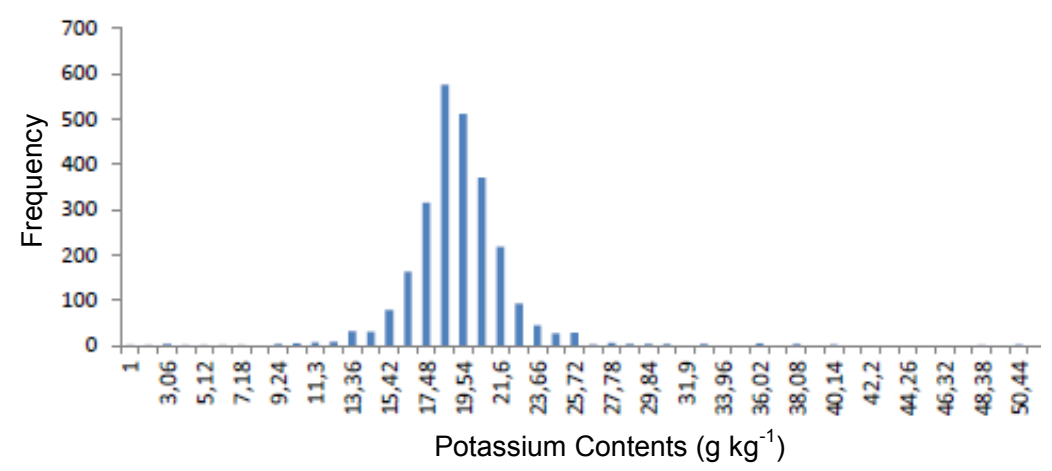

Figure 3. Frequency distribution histogram for potassium contents in 2543 soybean lots, expressed in $\mathrm{g} \mathrm{kg}^{-1}$

\subsection{Magnesium ( $\mathrm{Mg}$ )}

This element is responsible for enzymatic activation of several metabolic complexes, it is activator of enzymes related to the synthesis of carbohydrates and nucleic acids, active enzymes involved in respiration, photosynthesis, DNA and RNA synthesis, and structural arrange of the chlorophyll molecule (Taiz \& Zeiger, 2009), and an integral part of phytin (Ca and $\mathrm{Mg}$ salt of phosphoric inositol) that accumulates in seeds (Neptune, 1986). For an adequate growth and development of soybeans, the availability of 1.5 to $3 \mathrm{~g} \mathrm{~kg}^{-1}$ of fertilizer is prioritized (Vitti, 2006). Magnesium (Mg) contents available in 2543 soybean seed lots showed a maximum of $24 \mathrm{~g} \mathrm{~kg}^{-1}$ and a minimum of $0.65 \mathrm{~g} \mathrm{~kg}^{-1}$, with a range of $23.35 \mathrm{~g} \mathrm{~kg}^{-1}$ between the extremes verified for this nutrient (Figure 4). In a soybean production system, it is considered that for the production of one ton of seeds, about $1.91 \mathrm{~kg} \mathrm{ha}^{-1}$ of magnesium will be exported in the harvest (Bataglia \& Mascarenhas, 1977; Borket, 1986; Kavalco et al., 2015). 


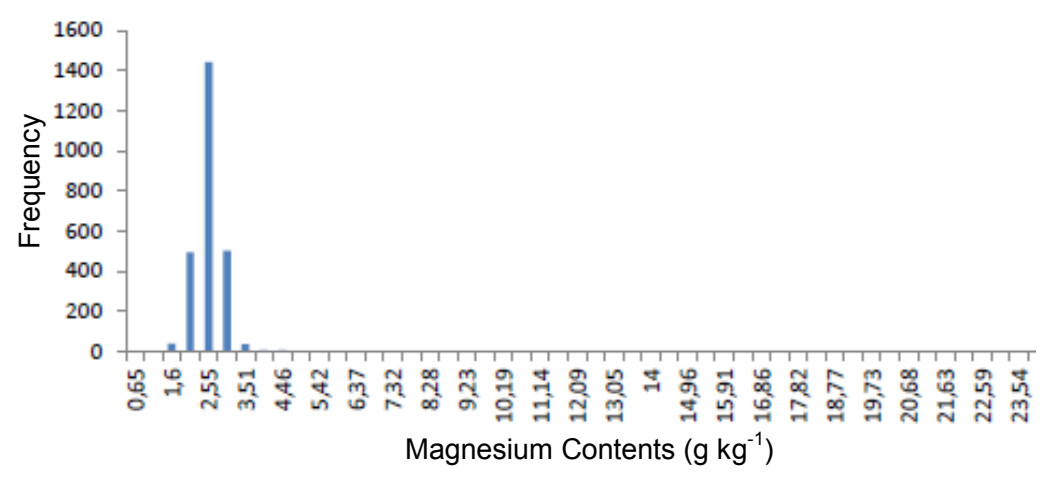

Figure 4. Frequency distribution histogram for magnesium contents in 2543 soybean lots, expressed in $\mathrm{g} \mathrm{kg}^{-1}$

\subsection{Calcium (Ca)}

This element takes place in the synthesis of cell-wall and middle lamella, separating newly divided cells (Taiz \& Zeiger, 2009). Calcium-rich soils with balanced fertilization result in better conformities of soybean and bean seed tegument, being more vigorous and tolerant to mechanical damages (Peske et al., 2012). Plants have developed mechanisms to restrict $\mathrm{Ca}$ transport, keeping low concentrations of this nutrient in phloem cells or precipitated as oxalate along sieve tubes and seed tegument (Mix \& Marschner, 1976; Fink, 1991), being indispensable for germination of pollen grains, pollen tube growth and wall synthesis (Malavolta, 1980; Carvalho et al., 2015). Calcium is required for the functioning of plant membranes, characterized as a secondary messenger of plant responses to environmental and hormonal effects (Adams et al., 1993; White \& Broadley, 2003). The calcium contents (Ca) for 2543 soybean seed lots expressed maximum values of $32 \mathrm{~g} \mathrm{~kg}^{-1}$ and minimum of $0.25 \mathrm{~g} \mathrm{~kg}^{-1}$, with amplitude of $1.75 \mathrm{~g} \mathrm{~kg}^{-1}$ (Figure 5). In a soybean seed production system, for harvesting one ton of seeds, about 1.8 to $3.0 \mathrm{~kg} \mathrm{ha}^{-1}$ of calcium is exported by the crop (Bataglia \& Mascarenhas, 1977; Borket, 1986; Szareski et al., 2016).

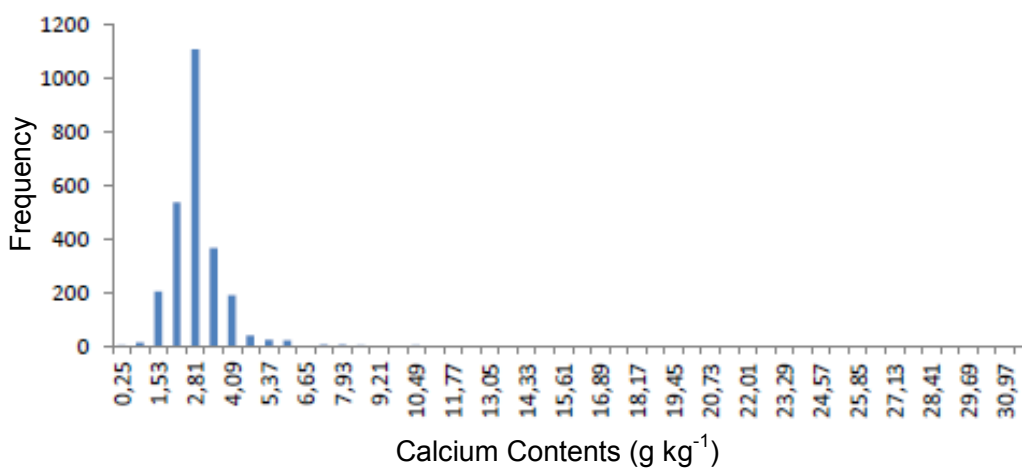

Figure 5. Frequency distribution histogram for calcium contents in 2543 soybean lots, expressed in $\mathrm{g} \mathrm{kg}^{-1}$

\subsection{Sulfur (S)}

Constituent of amino acids as cysteine and methionine, coenzymes and vitamins (acetyl coenzyme A, S-adenosyl methionine, biotin, B1 vitamin, pantothenic acid), which are essential for plant metabolism (Vitti, 1986; Taiz \& Zeiger, 2009). Studies have shown that 1 to $5 \mathrm{~g}$ of S per kilogram of plant dry matter are required for soybean growth and development, whereas cruciferous species demand 11 and $17 \mathrm{~g} \mathrm{~kg}^{-1}$ of sulfur (Vitti, 2006). The sulfur content (S) presented in the 2543 soybean seed lots showed maximum magnitude of $6 \mathrm{~g} \mathrm{~kg}^{-1}$ and a minimum of $0.14 \mathrm{~g} \mathrm{~kg}^{-1}$, with an amplitude of $5.46 \mathrm{~g} \mathrm{~kg}^{-1}$ between the observed extremes (Figure 6). For each ton of seed produced, 1.98 to $5.4 \mathrm{~kg} \mathrm{ha}^{-1}$ of sulfur are exported in the seeds (Borket, 1986; Olivoto et al., 2016). 


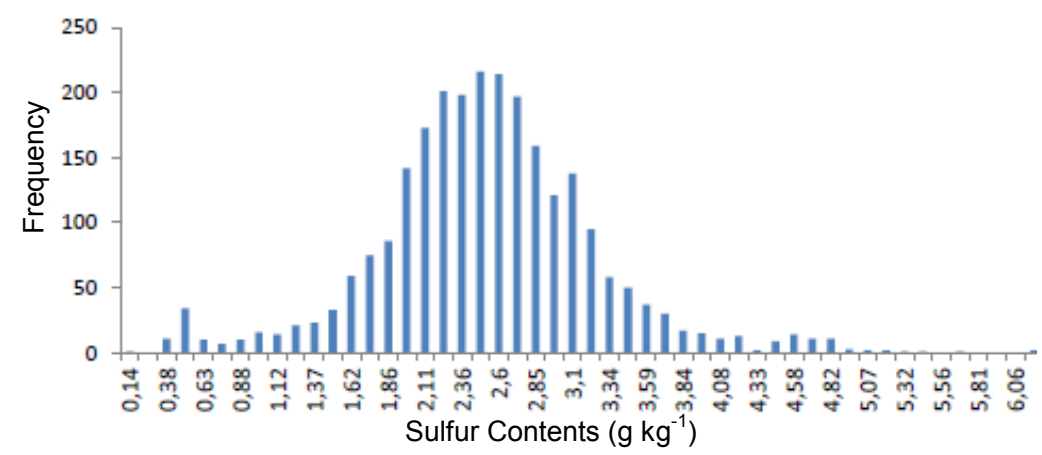

Figure 6. Frequency distribution histogram for Sulfur contents in 2543 soybean lots, expressed in $\mathrm{g} \mathrm{kg}^{-1}$

\subsection{Boron (B)}

This nutrient acts in cell division and differentiation, carbohydrates metabolism and transport, it also aids in the synthesis of cell-wall compounds, reproductive process, pollination, pollinic tube growth and seed production (Coetzer et al., 1990). Its deficiency is related to low germination of soybean seeds (Szareski et al., 2016). Suitable concentrations are defined ranging between 30 and $50 \mathrm{mg} \mathrm{kg}^{-1}$, as this amplitude allows the normal seed growth and development (Malavolta et al., 1989; Sá, 1994; Pais \& Jones Junior, 1996; Furlani, 2004). Boron levels (B) in 2543 lots of soybean seeds expressed maximum magnitudes of $89 \mathrm{mg} \mathrm{kg}^{-1}$ and minimum of 0.01 $\mathrm{mg} \mathrm{kg}^{-1}$, providing an amplitude of $88.99 \mathrm{mg} \mathrm{kg}^{-1}$ (Figure 7). For seed production fields, it is evident for each ton of seeds produced, an amount up to $5.68 \mathrm{~g} \mathrm{ha}^{-1}$ of boron is exported in the harvest (Bataglia \& Mascarenhas, 1977; Borket, 1986; Zimmer et al., 2016).

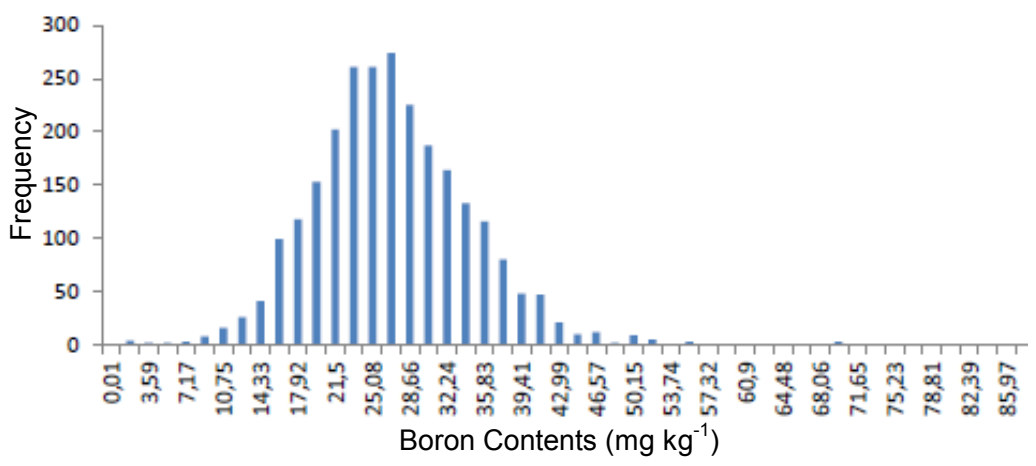

Figure 7. Frequency distribution histogram for boron contents in 2543 soybean lots, expressed in $\mathrm{mg} \mathrm{kg}^{-1}$

\subsection{Copper (Cu)}

Nutrient required at low concentrations, with slow mobility in plants, however possible of being translocated from vegetative structures to seeds. Deficiency of this element may result in non-viable pollen grains (Marschner, 1986; Carvalho et al., 2016). It associates to determining enzymes for redox reactions, which oxidize $\mathrm{Cu}^{+} \mathrm{Cu}^{2+}$, acting in the transport of electrons during photosynthetic reactions (Haehnel, 1984). Concentrations of 2 to 75 $\mathrm{mg}$ of cooper per kilogram of dry matter is prioritized, with optimum range from 5 to $20 \mathrm{mg} \mathrm{kg}^{-1}$ for adequate plant growth and development (Malavolta et al., 1989; Pais \& Jones Junior, 1996; Furlani, 2004). The copper $(\mathrm{Cu})$ contents expressed by 2543 soybean seed lots had a maximum of $74 \mathrm{mg} \mathrm{kg}^{-1}$ and a minimum of $0.5 \mathrm{mg} \mathrm{kg}^{-1}$, with an amplitude of $73.5 \mathrm{mg} \mathrm{kg}^{-1}$ (Figure 8). In soybean production systems, 16.80 to $18.7 \mathrm{~g} \mathrm{ha}^{-1}$ of copper (Bataglia \& Mascarenhas, 1977; Borket, 1986) is exported for each ton of seed produced. 


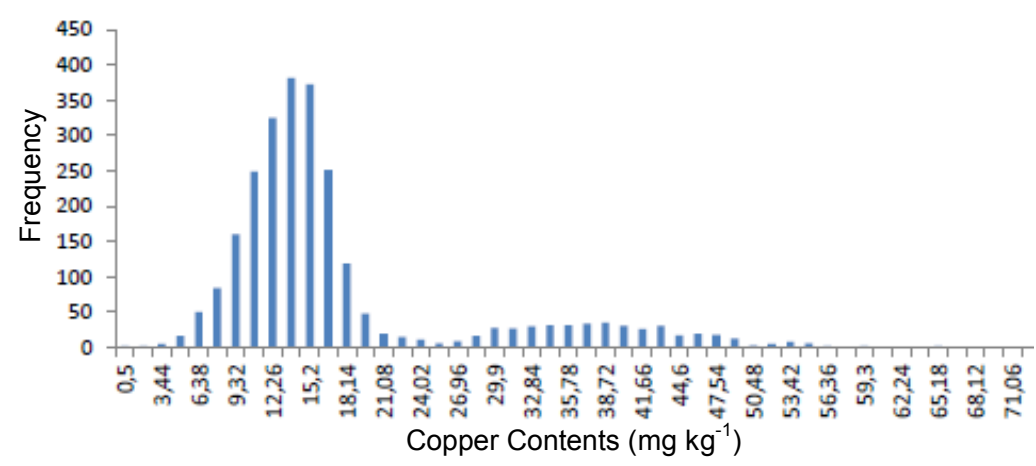

Figure 8. Frequency distribution histogram for copper contents in 2543 soybean lots, expressed in $\mathrm{m} \mathrm{kg}^{-1}$

\section{$3.9 \operatorname{Iron}(\mathrm{Fe})$}

It composes $5 \%$ of the entire earth's crust and is the second most abundant mineral element (Mengel \& Kirkby, 1987). Among its functions, iron acts as enzymatic activator, participates in oxidation reactions (cytochromes, leguemoglobin, catalase, peroxidase, superoxide dismutase) and is part of proteins. Its concentration varies from 10 to $1500 \mathrm{mg} \mathrm{kg}^{-1}$ of the plant's dry matter, this magnitude varies according to the part of the plant, species and growing environment (Malavolta et al., 1989; Pais \& Jones Junior, 1996; Furlani, 2004). The iron contents (Fe) obtained in 2543 seed lots of soybean presented a maximum of $900 \mathrm{mg} \mathrm{kg}^{-1}$ and a minimum of $10 \mathrm{mg} \mathrm{kg}^{-1}$, characterizing a large amplitude of $890 \mathrm{mg} \mathrm{kg}^{-1}$ between the extremes (Figure 9). In soybean seed production systems, it is estimated that 83.20 to $114 \mathrm{~g} \mathrm{ha}^{-1}$ of iron is exported at harvest for each ton of seed produced (Bataglia \& Mascarenhas, 1977; Borket, 1986; Dellagostin et al., 2016).

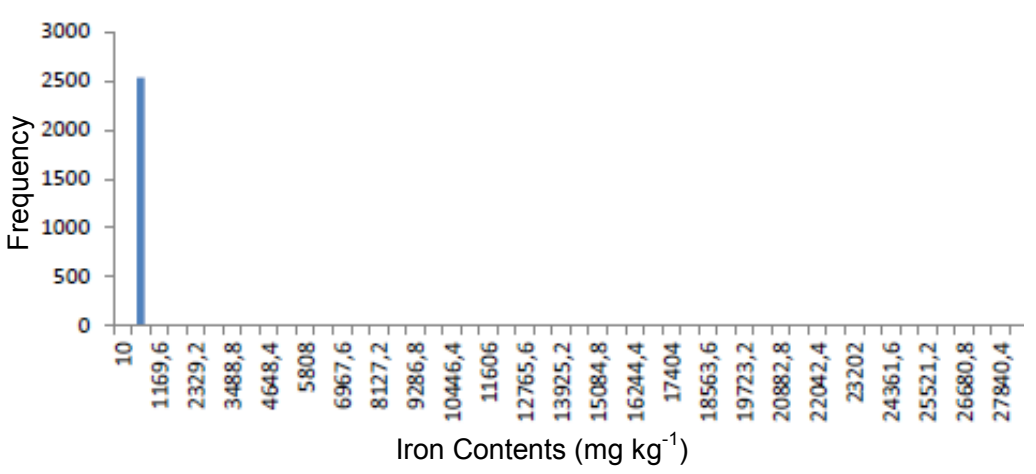

Figure 9. Frequency distribution histogram for iron contents in 2543 soybean lots, expressed in $\mathrm{mg} \mathrm{kg}^{-1}$

\subsection{Manganese (Mn)}

Nutrient involved in photosynthesis (photosystem II), taking place in the reaction enzymes which catalyze the initial stages of oxygen production (Marschner, 1986). Malavolta et al. (1997) defines that manganese has functionality in the cell elongation process and is related to tissue lignification (Marschner, 1995), providing impermeability to cellular wall (Mcdougall et al., 1996), effects on the capacity and speed of water absorption by the tegument, release of leachate during seeds imbibition in the germination process (Dubal et al., 2016). The concentrations of $\mathrm{Mn}$ in the plants vary from 5 to $1500 \mathrm{mg} \mathrm{kg}^{-1}$ of $\mathrm{Mn}$ in their dry matter, in contrast, the adequate concentrations are between 20 and $500 \mathrm{mg} \mathrm{kg}^{-1}$, which allow the best conditions for plants growth and development (Malavolta et al., 1989; Pais \& Jones Junior, 1996; Furlani, 2004). The manganese (Mn) contents evidenced in this study with 2543 lots of soybean seeds revealed maximum magnitudes of $455 \mathrm{mg} \mathrm{kg}^{-1}$ and a minimum of $5 \mathrm{mg} \mathrm{kg}^{-1}$, with amplitude of $450 \mathrm{mg} \mathrm{kg}^{-1}$ (Figure 10). In seed production fields, it is defined that $38.95 \mathrm{~g} \mathrm{ha}^{-1}$ of manganese are exported for each ton of seed produced (Bataglia \& Mascarenhas, 1977; Borket, 1986). 


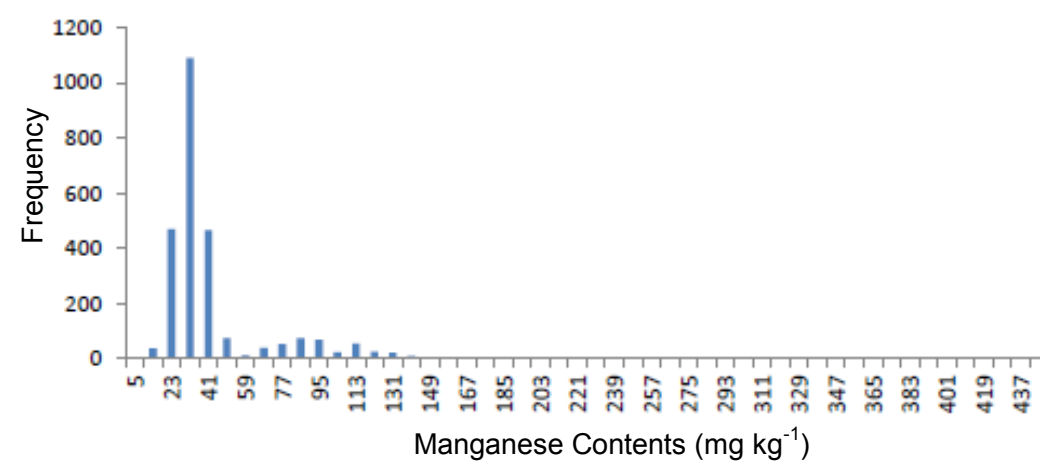

Figure 10. Frequency distribution histogram for manganese contents in 2543 soybean lots expressed in $\mathrm{mg} \mathrm{kg}^{-1}$

\subsection{Molybdenum (Mo)}

It acts on the biological process of nitrogen fixation, catalyzing the nitrogenase enzyme, which transforms atmospheric nitrogen into ammonia, acting together with the nitratoreductase enzyme, which assimilates nitrate in the plants (Taiz \& Zeiger, 2009). Besides its importance in biological nitrogen fixation process, molybdenum is characterized as the micronutrients most demanded by soybean, with great effects on seed productivity (Vargas \& Hungria, 1997; Broricket et al., 1992). Research by Guerra et al. (2006), observed that molybdenum and cobalt, when added to seeds, increase physiological quality and seed emergence (Jacob-Neto et al., 1988). The concentrations of Mo in plants vary from 0.01 to $500 \mathrm{mg} \mathrm{kg}^{-1}$ of dry matter, with adequate fractions of 0.6 and 10 $\mathrm{mg} \mathrm{kg}^{-1}$ (Pais \& Jones Junior, 1996; Furlani, 2004; Strobel et al., 2016). The molybdenum (Mo) contents expressed in the 2543 soybean seed lots showed a maximum of $179 \mathrm{mg} \mathrm{kg}^{-1}$ and a minimum of $0.02 \mathrm{mg} \mathrm{kg}^{-1}$, with amplitude of $178.98 \mathrm{mg} \mathrm{kg}^{-1}$ (Figure 11). It is estimated that, for each ton of seeds produced, $1.95 \mathrm{~g} \mathrm{ha}^{-1} \mathrm{of}^{-1}$ molybdenum are exported at harvest (Bataglia \& Mascarenhas, 1977).

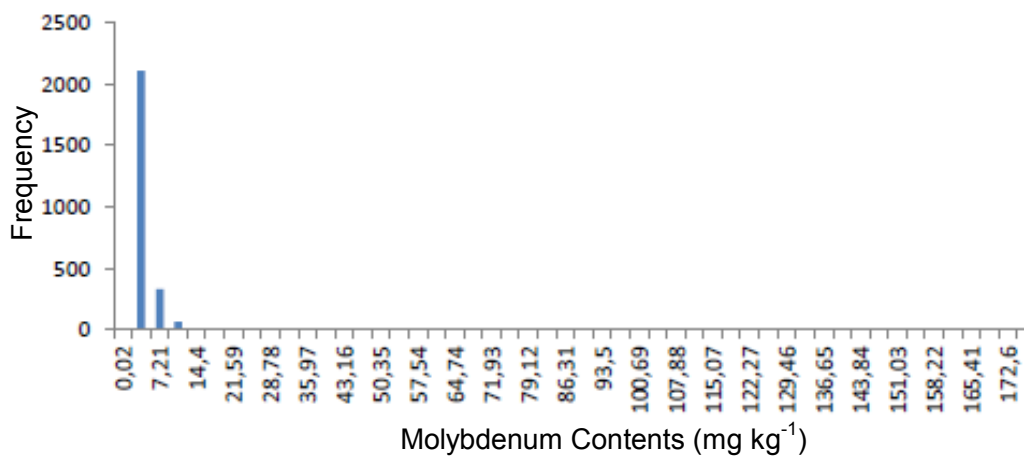

Figure 11. Frequency distribution histogram for molybdenum contents in 2543 soybean lots, expressed in $\mathrm{mg} \mathrm{kg}^{-1}$

\subsection{Zinc (Zn)}

This nutrient is absorbed in the form of $\mathrm{Zn}^{2+}$, through the roots and leaves, presents intermediate mobility (Dechen \& Nachtigall, 2006). Plants grown under zinc deficiency produce seeds with low concentrations of this nutrient, seedlings are less vigorous and seed productivity is altered (Rengel \& Graham, 1995; Genc et al., 2000). The concentrations of $\mathrm{Zn}$ may range from 3 to $150 \mathrm{mg} \mathrm{kg}^{-1}$ of plant dry matter (Malavolta et al., 1989; Pais \& Jones Junior, 1996; Furlani, 2004; Pelegrin et al., 2016). The zinc contents ( $\mathrm{Zn})$ for 2543 soybean seed lots evidenced maximum magnitude of $485 \mathrm{mg} \mathrm{kg}^{-1}$ and minimum of $3 \mathrm{mg} \mathrm{kg}^{-1}$, representing an amplitude of $482 \mathrm{mg}$ $\mathrm{kg}^{-1}$ (Figure 12). For soybean seeds production, an export of $36.12 \mathrm{~g} \mathrm{ha}^{-1}$ of zinc is considered for each ton of seeds harvested (Borket, 1986). 


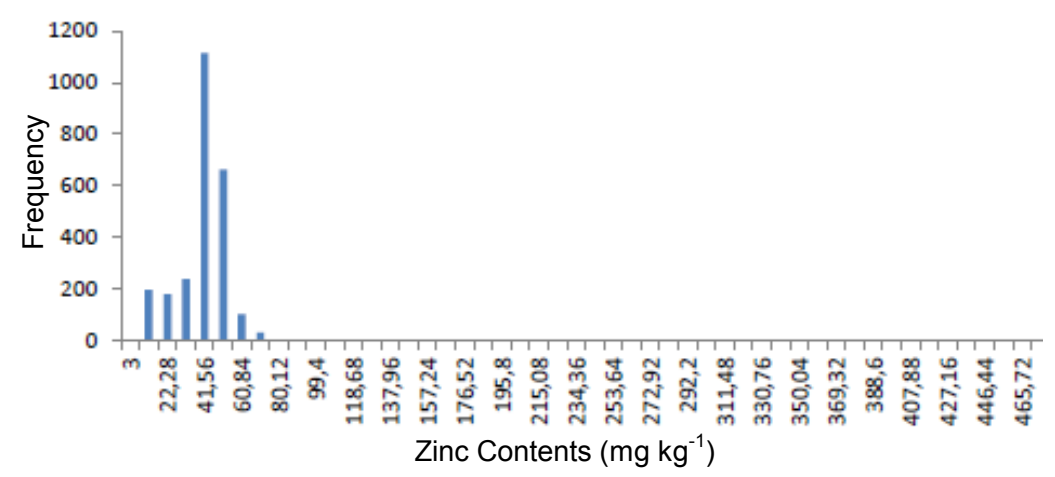

Figure 12. Frequency distribution histogram for zinc contents in 2543 soybean lots, expressed in $\mathrm{mg} \mathrm{kg}^{-1}$

\subsection{Sodium (Na)}

Characterized as an element poorly absorbed in ionic form, however its main purpose for plants mineral nutrition is to substitute $(95 \%)$ potassium in certain physiological, metabolic and osmotic functions (Marschner, 1995). The levels of sodium $(\mathrm{Na})$ in 2543 soybean seed lots showed a maximum of $475 \mathrm{mg} \mathrm{kg}^{-1}$ of seeds and a minimum of $0.5 \mathrm{mg} \mathrm{kg}^{-1}$ (Figure 13), with an amplitude of $574.5 \mathrm{mg} \mathrm{kg}^{-1}$.

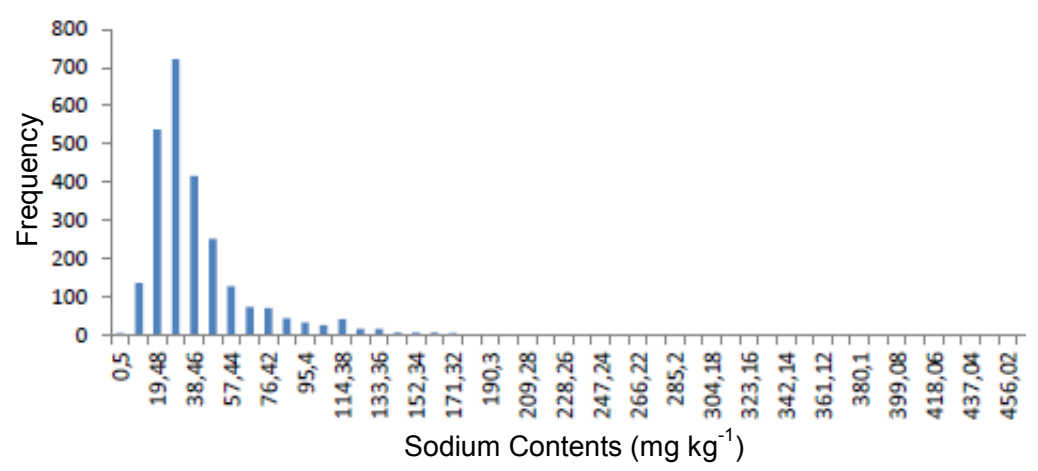

Figure 13. Frequency distribution histogram for sodium contents in 2543 soybean lots, expressed in $\mathrm{mg} \mathrm{kg}^{-1}$

\subsection{Aluminum (Al)}

The 2543 soybean seed lots evidenced large magnitudes, with $3800 \mathrm{mg} \mathrm{kg}^{-1}$ and minimum of $5 \mathrm{mg} \mathrm{kg}^{-1}$ thus, it was possible to verify an amplitude of $3795 \mathrm{mg} \mathrm{kg}^{-1}$ (Figure 14).

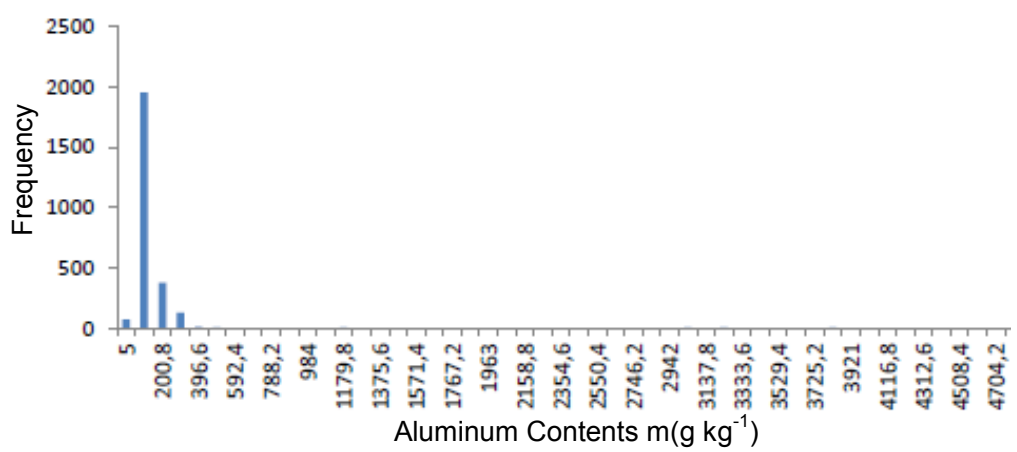

Figure 14. Frequency distribution histogram for aluminum contents in 2543 soybean lots, expressed in $\mathrm{mg} \mathrm{kg}^{-1}$ 
The most important macronutrients for soybean seeds production were nitrogen $\left(57.82 \mathrm{~g} \mathrm{~kg}^{-1}\right)$, potassium $(18.42$ $\left.\mathrm{g} \mathrm{kg}^{-1}\right)$, phosphorus $\left(3.74 \mathrm{~g} \mathrm{~kg}^{-1}\right)$, calcium $\left(2.24 \mathrm{~g} \mathrm{~kg}^{-1}\right)$, sulfur $\left(1.98 \mathrm{~g} \mathrm{~kg}^{-1}\right)$ and magnesium $\left(1.91 \mathrm{~g} \mathrm{~kg}^{-1}\right)$. However, the most demanded and exported micronutrients for soybean seeds production were iron $(83.20 \mathrm{mg}$ $\mathrm{kg}^{-1}$ ), manganese (38.93 mg kg $\mathrm{mg}^{-1}$ ), zinc (36.12 $\left.\mathrm{mg} \mathrm{kg}^{-1}\right)$, boron $\left(25.68 \mathrm{mg} \mathrm{kg}^{-1}\right)$, copper $\left(16.80 \mathrm{mg} \mathrm{kg}^{-1}\right)$, molybdenum $\left(1.95 \mathrm{mg} \mathrm{kg}^{-1}\right)$ and sodium $\left(35.43 \mathrm{mg} \mathrm{kg}^{-1}\right)$. Nitrogen and potassium were the most required nutrients for soybeans, followed by phosphorus, sulfur, calcium and magnesium. Phosphorus was more translocated (65\%), followed by nitrogen $(61 \%)$, potassium (53\%), sulfur (35\%), magnesium (30\%) and calcium $(25 \%)$. The micronutrient with the highest translocation was molybdenum $(71 \%)$, zinc $(66 \%)$, chlorine $(46 \%)$, copper (38\%), boron (26\%), manganese (23\%) and iron (15\%) (Sfredo, 2008). Determining the concentration of each nutrient and their dynamics for soybean seeds development is of fundamental importance for improving fertility management and fertilization recommendations in seed production areas, seeking not only for the largest production, but for the increase in physiological quality and maximum efficiency of the seeds at field conditions.

\section{Conclusion}

There is high variability of macro and micronutrients concentration in soybean seeds produced in several regions of Brazil. Nitrogen, potassium, phosphorus, and calcium are the most pronounced macronutrients in soybean seeds. Among the micronutrients, iron, manganese and zinc are those with more evidence. Understanding macro and micronutrients variability is critical for improving management and fertility treats in soybean seed production fields.

\section{References}

Adams, J. F., Hartozog, D. L., \& Nelson, D. B. (1993). Supplemental calcium application on yield, grade, and seed quality of runner peanut. Agronomy Journal, 85, 86-93. https://doi.org/10.2134/agronj1993.000219 $62008500010018 \mathrm{x}$

Bataglia, O. C., Mascarenhas, H. A. A., \& Tisselli Filho, O. (1997). Mineral composition of seeds of nine soy bean cultivars. Bragantia, 12 .

Bolland, M. D. A., \& Baker, M. J. (1989). High phosphorus concentration in Trifolium balansae and Medicagopolimorpha seed increases herbage and yelds in the field. Australian Journal of Experimental Agriculture, 29, 791-795. https://doi.org/10.1071/EA9890791

Borket, C. M. (1986). Extração de Nutrientes pela soja. Reunião de Pesquisa de Soja da Região Sul, 14, Chapecó (pp. 164-165). Anais. EMPASC/EMBRAPA-CNPSo.

Butler, G. W., \& Jones, D. I. H. (1973). Mineral biochemistry of herbage. In G. W. Butler \& R. W. Bailey (Eds.), Chemistry and biochemistry of herbage (pp. 127-162). London: Academic Press.

Carvalho, I. R., Korcelski, C., Pelissari, G., \& Hannus, A. D. (2013). Water Demand of Crop Agronomic Interest. Enciclopédia Biosfera, 9, 969.

Carvalho, I. R., Nardino, M., Demari, G., Szareski, V. J., Follmann, D. N., Pelegrin, A. J., ... Souza, V. Q. (2017). Relations among phenotypic traits of soybean pods and growth habit. African Journal of Agricultural Research, 12, 450-458. https://doi.org/10.5897/AJAR2016.11660

Carvalho, I. R., Nardino, M., Pelegrin, A. J., Hoffmann, J. F., Poleto, S. M., Ferrari, M., ... Maia, L. C. (2016). Estimate of genetic parameters in bioactive and micronutrients compounds of maize. African Journal of Agricultural Research, 11, 3123-3133. https://doi.org/10.5897/AJAR2016.11329

Carvalho, I. R., Souza, V. Q. de, Follmann, D. N., Nardino, M., Schmidt, D., Pelissari, G., \& Baretta, D. (2016). Physiological performance of soybean by regulating water Manitol. Agrarian (Online), 9, 34-43.

Carvalho, I. R., Souza, V. Q., Nardino, M., Follmann, D. N., Demari, G., Schmidt, D., ... Olivoto, T. (2015). Efeitos De Fungicidas Na Soja Com Hábito De Crescimento Determinado. Sodebras, 10, 30-34.

Carvalho, I. R., Souza, V. Q., Nardino, M., Follmann, D. N., Silva, A. D. B., Szareski, V. J., ... Olivoto, T. (2015). Associations Phenotypic between Physiological Traits of Soybean Contrasting Growth Habits. Global Science and Technology, 8, 30-40. https://doi.org/10.14688/1984-3801/gst.v8n3p30-40

Carvalho, N. M., \& Nakagawa, J. (2012). Sementes: Ciência, Tecnologia e Produção (5th ed., p. 590). Jaboticabal: FUNEP.

Clarkson, D. T., \& Hanson, J. B. (1980). The mineral nutrition of higher plants. Ann. Ver. Plant Physiol., 31, 239-298. https://doi.org/10.1146/annurev.pp.31.060180.001323 
Coelho, A. M., Cruz, J. C., \& Pereira Filho, I. A. (2002). Rendimento do milho no Brasil: Chegamos ao máximo? (pp. 1-37). Simpósio Sobre Rotação Soja/Milho No Plantio Direto. Anais... Potafos.

Coetzer, L. A., Robbertse, P. J., Stoffberg, E., Holtzhausen, L. S., \& Bernard, R. O. (1990). The effect of boron on reproduction in tomato (Lycopersicum esculentum) and bean (Phaseolus vulgaris). Plant Grond, 7(4), 212-217.

CONAB. (2017). Companhia Nacional de Abastecimento. Acompanhamento da Safra Brasileira de grãos, Primeiro levantamento, Outubro 2017 (p. 118). Brasília: CONAB.

Dechen, A. R., \& Nachtigall, G. R. (2006). Nutrição mineral de plantas (p. 342). Viçosa, MG: Sociedade Brasileira de Ciência do Solo.

Dellagostin, S. M., Bernardi, D., Nobrega, L. H. P., Dellagostin, D. M., Carvalho, I. R., Demari, G., ... Zimmer, P. D. (2016). Physiological Parameters Applied To The Soybean Seed Storage Techniques. International Journal of Current Research, 8, 41523-41527.

Demari, G., Perondi, D., Carvalho, I. R., Nardino, M., Follmann, D. N., Szareski, V. J., ... Souza, V. Q. (2016). Velocidade De Semeadura Na Produtividade Da Soja Monsoy 5947 Ipro®. Revista Sodebras, 11, 205-210.

Dubal, I., Troyjack, C., Koch, F., Szareski, V. J., Pimentel, J. R., Nardino, M., ... Pedo, T. (2016). Effect of temperature on bean seed germination: vigor and isozyme expression. American Journal of Agricultural Research, 1(5), 01-09.

Ferrari, M., Nardino, M., Carvalho, I. R., Pelegrin, A. J., Belle, R., Szareski, V. J., ... Souza, V. Q. (2015). Water Absorbent: Alternative for Greater Tolerance to Drought. Global Science and Technology, 8, 21-29. https://doi.org/10.14688/1984-3801/gst.v8n3p21-29

Ferrari, M., Pelegrin, A. J., Souza, V. Q., Nardino, M., \& Carvalho, I. R. (2014). Efections on Yield Components of Different Treatment of Seeds and Leaf in the Soybean. Enciclopédia Biosfera, 10, 532-538.

Fink, S. (1991). The micromorphological distribution of bound calcium in needles of Norway spruce (Piceaabies (L.) Karst.). New Phytol., 119, 33-40. https://doi.org/10.1111/j.1469-8137.1991.tb01005.x

Follmann, D. N., Souza, V. Q., Nardino, M., Carvalho I. R., \& Demari, G. (2014). Different associations for additives in pre-seeding on soybean and yours effects on quality of seed produced. Enciclopédia Biosfera, 10, 1284-1292.

Furlani, A. M. C. (2004). Nutrição Mineral. In G. B. Kerbauy (Eds.), Fisiologia vegetal (pp. 40-75). Rio de Janeiro, Guanabara Koogan.

Genc, Y., Mcdonal, G. K., \& Graham, R. (2000). Effect of seed contento $\mathrm{n}$ early growth of barley (Hordeum vulgare L.) under low and adequade soil zinc supply. Australian Jounal of Agricultural Research, 51(1), 37-45. https://doi.org/10.1071/AR99045

Grant, C. A., Flaten, D. N., Tomasiewicz, D. J., \& Sheppard, S. C. (2001). A importância do fósforo no desenvolvimento inicial da planta (p. 16). Informações Agronômicas, Potafós. Retrieved from http://www.ipni.net/publication/ia-brasil.nsf/0/43C5E32F5587415C83257AA30063E620/\$FILE/Page1-5-9 5.pdf

Guerra, M. E. C., Medeiros Filho, S., \& Gallão, M. I. (2006) .Morfologia de sementes, de plântulas e da germinação de Copaifera langsdorfii Desf. (Leguminosae Caesalpinioideae). Cerne, 12(4), 322-328.

Haehnel, W. (1984). Photosynthetic electron transport in higher plants. Annu. Ver. Plant Physiol., 35, 659-693. https://doi.org/10.1146/annurev.pp.35.060184.003303

Jacob-Neto, J., Thomas, R. J., \& Franco, A. A. (1988). Variação estacional da concentração de molibdênio nos nódulos e demais partes da planta de feijoeiro (Phaseolus vulgaris L.). Turrialba, 38(1), 51-58.

Kavalco, S. A. F., Souza, V. Q., Follmann, D. N., Carvalho, I. R., Nardino, M., \& Demari, G. (2015). Development of Soybeans with Hormones Applications in Different Crop Densities. Brasilian Journal of Sustainable Agriculture, 4, 1-10.

Koo, R. C. J. (1985). Potassium nutrition of citrus. In R. S. Munson (Ed.), Potassium in agriculture (pp. 1077-1086). Madison, American Society of Agronomy, Crop Science Society of America, Soil Science Society of America. 
Lindhauer, M. G. (1985). The role of potassium in the plant with emphasis on stress conditions (water, temperature, salinity). Proceedings of the Potassium Symposium (pp. 95-113). Pretoria, International Potash Institute and Fertilizer Society of South Africa.

Lott, J. N. A. (1984). Accumulation of seed reserves of phosphorus and other minerals. In D. R. Murray (Ed.), Seed Physiology (pp. 139-166). New York.

Macdougall, G. J., Morrison, I. M., Stewart, D., \& Hillman, J. R. (1996). Plant cell walls as dietary fibre: Range, structure, processing and function. Journal Science Food Agriculture, 70(2), 133-150. https://doi.org/ 10.1002/(SICI)1097-0010(199602)70:2\%3C133::AID-JSFA495\%3E3.0.CO;2-4

Magalhães, W. A., Megaioli, T. G., Freddi, O. S., \& Santos, M. A. (2015). Measurement of nutrient concentration in soybean seeds. Revista de Ciências Agroambientais, 13(2) 95-100.

Malavolta, E. (1980). Elementos de nutrição mineral de plantas (pp. 251-254). São Paulo, Agronômica "Ceres".

Malavolta, E., Vitti, G. C., \& Oliveira, S. A. (1989). Avaliação do estado nutricional das plantas: Princípios e aplicações (p. 201). Piracicaba, Potafos.

Malavolta, E., Vitti, G., \& Oliveira, S. A. (1997). Avaliação do estado nutricional das plantas: Princípios e aplicações (2nd ed., p. 319). Piracicaba: Potafos.

Marcos-Filho, J. (2015). Fisiologia de Sementes de Plantas Cultivadas (2nd ed., p. 660). Abrates, Londrina, PR, Brasil.

Marschner, H. (1986). Mineral nutrition of higher plants (p. 407). London: Academic Press INC.

Marschner, H. (1995). Mineral nutrition of higher plants (2nd ed., p. 889). San Diego: Academic Press.

Meier, C., Meira, D., Olivoto, T., Follmann, D. N., Nardino, M., Carvalho, I. R., ... Souza, V. Q. (2016). Morphological traits and yield components of second-crop soybeans in Rio Grande do Sul state, Brazil. Australian Journal of Basic and Applied Sciences, 10, 81-88.

Meira, D., Souza, V. Q., Carvalho, I. R., Nardino, M., Follmann, D. N., Meier, C., ... Pelegrin, A. J. (2015). Plastochron and morphological traits of soybean with indeterminate growth habit. Revista Cultivando o Saber, 8, 184-200.

Mengel, K. (1997). Impact of potassium on crop yield and quality with regard to economical and ecological aspects. In A. E. Johnston (Ed.), Food Security in the Wana Region, the Essential Need for Balanced Fertilization (pp. 157-174). Izmir, Turkey.

Mengel, K., \& Kirkby, E. A. (1987). Principles of plant nutrition (4th ed., p. 687). Dordrecht, Kluwer Academic.

Meurer, E. J. (2006). Nutrição mineral de plantas (p. 292). Viçosa, MG: Sociedade Brasileira de Ciência do Solo.

Mix, G. P., \& Marschner, H. (1976). Calcium-Umlagerung in Bohnenfrüchten währenddês Samenwachstums. Z. Pflanzenphysiol., 80, 354-366. https://doi.org/10.1016/S0044-328X(76)80118-3

Neptune, A. M. L. (1986). O Mg como nutriente para as culturas. Situação Atual E Perspectiva Na Agricultura (p. 144). Anais. São Paulo.

Olivoto, T., Carvalho, I. R., Nardino, M., Ferrari, M., Pelegrin, A. J., Follmann, D. N., ... Souza, V. Q. (2016). Sulfur and nitrogen effects on industrial quality and grain yield of wheat. Revista de Ciências Agroveterinárias, 15, 24-33. https://doi.org/10.5965/223811711512016024

Pais, I., \& Jones Junior, J. B. (1996). The handbook of trace elements (p. 223). Boca Raton, St. Lucie Press.

Pauletti, V. (2004). Nutrientes e interpretações (2nd ed.).

Pelegrin, A. J., Carvalho, I. R., Nardino, M., Ferrari, M., Szareski, V. J., Belle, R., ... Souza, V. Q. (2016). Performance of Resistant Soybean to Asian Rust in Different Environments in Rs. International Journal of Current Research, 8, 38398-38401.

Pelegrin, A. J., Carvalho, I. R., Nardino, M., Ruwer, P. H., Demari, G., Szareski, V. J., ... Souza, V. Q. (2016). Tiametoxam E Chlorantraniliprole sobre a emergência e crescimento do cultivar Don Mario 7.0i. Revista Sodebras, 11, 34-38.

Peske, S. T., Villela, F. A., \& Meneghello, G. E. (2012). Sementes: Fundamentos Cientificos e Tecnológicos (3rd ed., p. 573). Pelotas: Ed. Universitária.

Raij, B. V. (1991). Fertilidade do solo e adubação (p. 343). Piracicaba, Ceres. 
Rengel, Z., \& Graham, R. D. (1995). Importance of seed Zn content for wheat growth on Zn-deficient soil-II grain yield. Plant and Soil, 173(3), 267-274. https://doi.org/10.1007/BF00011464

Sá, M. E. (1994). Importância da adubação na qualidade de semente. In M. E. Sá, \& S. Buzzetti (Eds.), Importância da adubação na qualidade dos produtos agrícolas (pp. 65-98). São Paulo: Ícone.

Sfredo, G. J. (2008). Soja no Brasil: Calagem, adubação e nutrição mineral (p. 148). Londrina: Embrapa Soja.

Shuman, L. M. (1994). Mineral Nutrition. In R. E. Wilkinson (Ed.), Plant-environment interactions (pp. 149-182). New York, Marcel Dekker.

Silva, A. D. B., Souza, V. Q., Follmann, D. N., Nardino, M., \& Carvalho, I. R. (2015). Physiological quality of soybean seeds late growth. Enciclopédia Biosfera, 11, 1618-1623,

Souza, V. Q., Bellé, R., Ferrari, M., Pelegrin, A. J., Caron, B. O., Nardino, M., ... Carvalho, I. R. (2015). Yield Components in Combinations of Fungicides and Insecticides and Path Analysis in Soybean. Global Science and Technology, 8, 167-176. https://doi.org/10.14688/1984-3801/gst.v8n1p167-176

Souza, V. Q., Follmann, D. N., Nardino, M., Baretta, D., Carvalho, I. R., Caron, B. O., ... Demari, G. H. (2015). Production of Soybean Seeds and Seed Vigor of Produced with Different Treatment of Seeds. Global Science and Technology, 8, 157-166. https://doi.org/10.14688/1984-3801/gst.v8n1p157-166

Strobel, T., Koch, F., Aisenberg, G. R., Szareski, V. J., Carvalho, I. R., Nardino, M., ... Aumonde, T. Z. (2016). Physical and physiological quality of soybean seeds harvested under different trial systems after storage period. Australian Journal of Basic and Applied Sciences, 10, 124-130.

Szareski, V. J., Carvalho, I. R., Nardino, M., Demari, G. H., Bahry, C. A., Kehl, K., ... Aumonde, T. Z. (2016). Phenotype stability of soybean genotypes for characters related to the physiological quality of seeds produced under different environmental conditions. Australian Journal of Basic and Applied Sciences, 10(15), 279-289.

Szareski, V. J., Carvalho, I. R., Nardino, M., Pelegrin, A. J., Ferrari, M., Gaviraghi, R., ... Souza, V. Q. (2016). Competition of soybean genotypes cultivated in lowlands of Rio Grande do Sul, Brazil. International Journal of Current Research, 8, 39714-39718.

Szareski, V. J., Souza, V. Q., Carvalho, I. R., Nardino, M., Follmann, D. N., Demari, G., ... Olivoto, T. (2015). Growing Environment and Its Effects on Morphological Characters and Dietetic Soy. Brasilian Journal of Sustainable Agriculture, 5, 1-10.

Szareski, V. J., Zanatta, E., Koch, F., Aisenberg, G. R., Demari, G., Kehl, K., ... Aumonde, T. Z. (2016). Pre-harvest Desiccation and Seed Production in Soybean Crops. International Journal of Current Research, $8,41534-41537$.

Ta, C. T., \& Weiland, R. T. (1992). Nitrogen partitioning in maize during ear development. Crop Sciense, 32 , 443-451. https://doi.org/10.2135/cropsci1992.0011183X003200020032x

Taiz, L., \& Zeiger, E. (2009). Fisiologia vegetal (4th ed., pp. 96-114). Porto Alegre, Artmed.

Trigo, L. F. N., Peske, S. T., Gastal, M. F., Vahl, L. C., \& Trigo, M. F. O. (1997). Efect of phosphorus concentration in the seed on the yeld of soybean. Revista Brasileira de Sementes, 19(1), 111-115. https://doi.org/10.17801/0101-3122/rbs.v19n1p111-115

Usherwood, N. R. (1985). The role of potassium in crop quality. In R. S. Munson (Ed.), Potassium in agriculture (pp. 489-513). Madison, American Society of Agronomy.

Vargas, M. A. T., \& Hungria, M. (1997). Biologia dos solos dos cerrados (p. 524). Planaltina: Embrapa.

Vitti, G. C. (2006). Nutrição mineral de plantas (p. 432). Viçosa, MG: Sociedade Brasileira de Ciência do Solo.

Vitti, G. C., Malavolta, E., \& Ferreira, M. E. (1986). Respostas de culturas anuais e perenes à aplicação de S. Enxofre E Micronutrientes Na Agricultura Brasileira, Londrina. Anais. Londrina, Embrapa-CNPso/IAPAR/ $\mathrm{SBCS}$.

Williams, L. E., \& Miller, A. J. (2001). Transporters responsible for the uptake and partitioning of nitrogenous solutes. Ann. Rev. Plants Physiological, 52, 659-688. https://doi.org/10.1146/annurev.arplant.52.1.659

Zimmer, G., Koch, F., Carvalho, I. R., Szareski, V. J., Demari, G., Nardino, M., ... Pedo, T. (2016). Seed Quality and Initial Performance of Seedlings of Soybean Produced Off-Season in Rio Grande Do Sul, Brazil. International Journal of Current Research, 8, 40325-40329. 


\section{Copyrights}

Copyright for this article is retained by the author(s), with first publication rights granted to the journal.

This is an open-access article distributed under the terms and conditions of the Creative Commons Attribution license (http://creativecommons.org/licenses/by/4.0/). 